\title{
The Importance Of The Soft Skill Influence For The Tourism Community For The Satisfaction Of Tourists At Parbaba Beach In Samosir Island
}

\author{
Sumihar Sebastiana Sitompul \\ Medan Tourism Polytechnic \\ Medan, Indonesia \\ sumiharsebastiana2@gmail.com
}

\author{
Femmy Indriani Dalimunthe \\ Medan Tourism Polytechnic \\ Medan, Indonesia \\ femmydalimunthe@yahoo.co.id
}

\author{
Muhammad Halfi Indra Syahputra \\ Medan Tourism Polytechnic \\ Medan, Indonesia \\ halfimedan@gmail.com
}

\begin{abstract}
The research aims to analyze the importance of soft skill influenced for the tourism community for the purposed of tourism satisfaction. This is a quantitative research and the data analyzed of tourism satisfaction. This is a quantitative research and the data analyzed by using SPSS 16.0. This research shows that: The influenced of soft skills had important things for giving the services to the tourism community to get the tourist satisfaction, We known from the answer of the respondence that they get the good services, the prove the payment, honestly, the visitors get the same quality of services from the tourism community. But they still needed to developed their team work. All of this purposes to get the satisfaction from the tourism whose visiting their place.
\end{abstract}

Key words : tourism community, soft skill, guest satisfaction

\section{INTRODUCTION}

In order to meet the achievement of econometric targets, it is felt that the improvement of human resources is still not strong enough to be voiced amid increasing demands for the need to improve performance in the tourism sector. How much foreign exchange is produced, how much employment opportunities, how many tourists come to visit, there is an impression that only highlights that our attention is mainly still based on quantitative aspects (Brohman, 1999 in Janianton, 2002).

In accordance with the Tourism Development Goals of the Tourism Law No. 10 of 2009 concerning the purpose of tourism development:

"to increase economic growth, improve people's welfare, eradicate poverty, overcome unemployment, preserve nature, environment and resources, promote culture, elevate the nation's image, foster a sense of love for the homeland, strengthen national identity and unity, strengthen unity among nations".

Indeed, the quality of human resources is believed to be able to directly determine the quality of tourism products and services because each tourist destination area is required to be able to improve the quality of human resources (Priowirjanto in Janianton, 2002), the preparation and implementation of labor competency standards (Parwoto in Janianton, 2002).

Soft skills are basic abilities that need to be nurtured within a person so that they can motivate himself or herself and others, be responsible, build relationships, communicate, negotiate, adapt to the environment, create, innovate and entrepreneurship, lead, build cooperation, manage resources and so forth. Soft skills are sociological terms that refer to a set of personality traits, social grace, and facilities with language, personal habits, hospitality, and optimism. Soft skills complement hard skills, which are the technical requirements of the workers. Soft skills can be a skill that must be possessed by every profession. If someone has characteristics or attributes like this then surely the person has competitiveness. In order for a certain area or object of tourism to have competitiveness, it must have an advantage compared to other regions or attractions.

One of the famous tourist attractions is Lake Toba. This is one of the ten tourist attractions that are prioritized by the government. The government wants Lake Toba to become an international tourism destination, and therefore the government will manage it in an integrated manner. Lake Toba is one of the tourist destinations visited by many tourists, in which one of the famous objects is the White Sand Beach in the Parbaba region. Natural beauty on the white sand beach of Parbaba is a tourist attraction. For this reason, the quality of service is very important. The role of soft skills to improve quality services that must be owned by tourism community is very important. Thus the tourists will be interested in coming to visit the white sand beach of Parbaba, and will come again and again if they get satisfaction with the services provided by the community as tourism community in the tourist attraction.

The definition of service, in short, by Gerson (2004) is a means to achieve satisfaction. The aim is to provide satisfying services so that customers will continue to come. Conversely, if the level of satisfaction given by the community as tourism actors is not as expected, then visitors will not feel satisfied.

Based on research conducted on the services provided by tourism community on the white sand beach of Parbaba, in fact, the people there really need an important role played by soft skills. Function and role of soft skills are needed to increase tourist satisfaction. This is important, because there are still a lot of tourist complaints and dissatisfaction caused by the lack of enthusiasm and lack of service provided and the lack of public friendliness in serving tourists who come to the white sand beach of 
Parbaba, especially when tourists are crowded during long holidays.

\section{Formulation of the Problem}

Based on the description above about the background of the problem, the main problem in this study are:

"How is the role of soft skills in society as tourism community and their influence on tourist satisfaction at the white sand beach of Parbaba in Samosir Regency?"

\section{Study Objectives}

1. To determine the extent of satisfaction of customers who come to visit the white sand beach of Parbaba.

2. As input and information for tourism community in the white sand beach of Parbaba.

\section{Benefits of Study} benefits:

This research is expected to produce the following

1. Benefit for Regency Government

The results of this study are expected to be input, suggestions, and thought contributions for the local government in providing quality services in the area of tourist objects with a soft skill approach

2. Benefit for the Researcher

The results of this study are expected to improve knowledge and practical experience in the tourism sector.

3. Benefit for the Community as Tourism Actors The results of this study are expected to add insight and knowledge about the role played by soft skills in providing services to tourists.

\section{CONCEPTUAL FRAMEWORK}

\subsection{Definition of Soft Skill}

The definition of soft skills according to Wikipedia of the English version is as follows: "Soft skills lead to groups of personality traits, social friendliness, equipped with language, personal habits, friendliness, and a sense of optimism that makes people have a higher value. Soft skills complement the hard skills needed in job execution techniques" (Wikipedia, 2007).

The ability to treat by feeling it yourself and understanding the feelings of others in certain situations, and helping to improve academic abilities and cognitive abilities (IQ) by understanding fellow human beings. This ability is known as Emotional Intelligence or Soft skill (Mangala, 2010).

In the world of work, soft skills, aside from hard skills, play a very important role in taking the initiative so that people can cooperate and persevere. Basically, every human being has their own soft skills, but the implementation may be different. Soft skills develop one's personality to be better.
Elfindri et al. (2011: 67) defines soft skills as follows:

Soft skills are skills and qualifications of life, for ourselves, in groups or in society, and with the Creator. Having soft skills will make someone's presence more real in the midst of society. Communication skills, emotional skills, language skills, group skills, ethics and morals, polite in spiritual skills.

Elfindri et al. (2011: 75) argue that soft skills are as follows:

All traits that cause the functioning of the hard skills possessed by someone. Soft skills can determine the direction of utilization of hard skills. If someone has it well, then the knowledge and skills he or she master can bring prosperity and comfort to those who have it and the environment. Conversely, if someone does not have good soft skills, then hard skills can endanger himself or herself and others.

According to Iyo Mulyono (2011: 99), "soft skill is a complement of hard skills. This type of skill is part of a person's intellectual perspicacity, and is often used as a condition for obtaining certain positions or jobs".

So it can be formulated that basically soft skills are abilities that are inherent in a person, but can be developed to the maximum and needed in the realm of work as a complement to the ability of hard skills. The existence of hard skills and soft skills should be balanced and in line.

Illah Sailah in a manuscript of her book entitled 'Soft Skill Development in Universities in 2008' (Dirjen Dikti), citing the following definitions:

- A person's skills in dealing with others (interpersonal skills) and self-managing skills (intrapersonal skills) that is able to develop one's performance to the fullest.

- Meanwhile examples of skills in dealing with others, among others, are: (a) communication skills, (b) relationship building, (c) motivation skills, (d) leadership skills, (e) self-marketing skills, (f) negotiation skills, (g) presentation skills, (h) public speaking skills, and others.

By using the definition above, it appears that soft skills are an important part of a person's competence to be able to "succeed" in his life.

If every profession is required to have different hard skills, this is not the case with soft skills, because these skills are competencies that should be owned by everyone regardless of their profession.

List of soft skills are:

- Honesty

- Responsible

- Fair

- Ability to cooperate

- Adaptability

- Communication skills

- Tolerant

- Respect for others

- Ability to make decisions

- Problem solving ability 
Coates in I Made Supartha Utama et al. (2009) mentions that intrepersonality is a skill that a person has in managing himself, such as time management, stress management, change management, transformational character, creative thinking, having positive goals, and quick learning techniques. Meanwhile interpersonality is the skill to relate or interact with the community group setting and work setting as well as interaction with individual humans so as to be able to develop maximum performance, ability to motivate, leadership abilities, negotiation skills, presentation skills, communication skills, ability to establish relationships, and the ability to speak in public.

Sharma tabulates the soft skill elements that a person must possess. Each soft skill contains sub-skills that can be categorized as skills that are individually needed and as good skills to have.

In Wikipedia (2010) written that soft skills is a sociological term for a person's Emotional Quotient (EQ) which is the ability of how people relate between one another, such as communicating, listening, giving feedback, cooperating in a team, solving problems, contribute to meetings, and resolve conflicts. The leaders in each level need all of these abilities because their tasks are related to forming and developing teams, leading meetings, motivating, encouraging innovation, finding solutions to problems, making decisions, guiding and the like. Soft skills can be used and needed in various fields of work (transferable skills), while hard skills or technical skills are only needed in one place or field of work / industry in accordance with a person's scientific field.

\section{Function of Soft Skill in the Tourism Industry}

Soft skills consisting of character, attitude and life values, social and interpersonal skills, are important factors in almost all aspects of life, especially in the world of work.

An employee is not only required to master technical competencies, such as how to apply concepts that have been learned in the core of his knowledge, but also required to have strong character, a strong attitude to life, skills to connect with others, and other personal skills. Employees like this are considered to have more readiness and high quality work.

The definition of the tourism industry in this study is a collection of various companies, which are needed directly or indirectly by tourists during their tour to tourism destinations. Gee \& Sola (1997) states that the tourism industry involves a variety of service companies, especially those related to the needs of tourists during tourist trips such as hotels, airlines, and tourist attraction.

In Law No. 10 of 2009 concerning Tourism, it is stated that the tourism industry is a collection of tourism businesses that are interrelated in order to produce goods and / or services to meet the needs of tourists in the implementation of tourism (Sunaryo, 2013). Thus it can be said that in the tourism industry there needs to be several companies needed by tourists during tourism activities.
These companies are needed by tourists during the trip starting from their area of origin until they return there.

Conceptual Framework

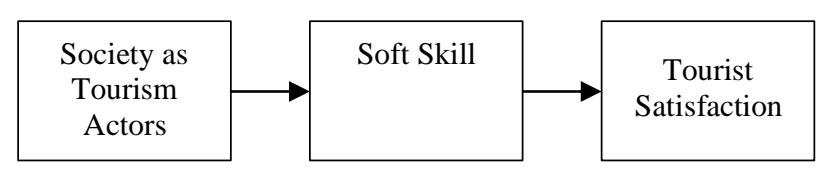

\section{RESEARCH METHODOLOGY}

\subsection{Type / Nature of Research}

This study is a causal research that analyzes how a variable influences other variables, where independent variable is treated in a controlled manner by the researcher to determine their impact on the dependent variable. Independent variable is soft skills and dependent variable is people as tourism actors.

This research is exploratory in nature by conducting a survey directly to the field to collect data needed, both primary data and secondary data. Primary data is data obtained directly from respondents while secondary data is data obtained indirectly from respondents but related to the data needed in the study.

\subsection{Research Site}

This research was conducted at the location of the tourist attraction, namely the white sand beach of Parbaba in Samosir Regency.

\subsection{Population and Sample}

Population is an area of generalization which consists of objects that have the quality of certain characteristics set by the researcher to be studied and then conclusions based on the population are taken (Sugiyono, 2012). The population in this study is the tourists who come to the location of tourist attractions. Because of the large population, a sample is taken from it.

\section{RESULTS AND DISCUSSION}

\subsection{Results of Research}

\subsubsection{Overview of Samosir Regency}

Samosir Regency is one of the regions in North Sumatra Province that has the potential as an agricultural and tourism area. In order to increase the role of the tourism sector in supporting the regional economy, regional income and community welfare of Samosir Regency, an increase in the role of soft skills is deemed necessary for the community as tourism actors in one of the tourist attractions in this area, namely the white sand beach in Parbaba.

The opportunity to increase tourist arrivals continuously is quite large because the white sand beach of Parbaba has enough potential to produce prosperity for the community as tourism actors in this area. In order for the 
potential of tourism, which is a mainstay for the community as tourism actors on the white sand beach of Parbaba, can develop and have become a welfare support for the local community, the role of soft skills is needed by society as tourism actors in providing satisfying services to tourists who visited this attraction.

Samosir Regency is new regency separated from Toba Samosir Regency in accordance with the Law of the Republic of Indonesia No. 36 of 2003 on December 18, 2003 concerning the establishment of Samosir Regency and Serdang Bedagai Regency. The establishment of Samosir Regency as a new regency is the first step to begin accelerating development towards a more prosperous society.

Samosir Regency has areas of tourism potential based on natural scenery, spiritual tourism, agricultural tourism, cultural tourism, and the waters of Lake Toba.

\subsection{Discussion}

The role analysis played by soft skills of the community as tourism actors in generating satisfaction of tourists. In this discussion the interpretation will be carried out about the results of the analysis carried out in the study. The discussion in this section will be explained based on the relationship or influence between the independent variable and the dependent variable. In this case the researcher only has 1 independent variable, namely the role of soft skill (X), and 1 dependent variable namely tourist satisfaction $(\mathrm{Y})$.

\subsubsection{The role of soft skills $(X)$ in tourist satisfaction $(Y)$}

Analysis of the role of soft skills in tourist satisfaction in tourism objects, namely the white sand beach of Parbaba can be expressed through the analysis stages used through SPSS software on the data on the response of respondents as the object of research.

The role of soft skills in tourist satisfaction can be analyzed using correlation tests with the following stages:

a. Determine hypotheses with one-sided tests, where:

Ho $: \beta=0$. There is no relationship between soft skills and tourist satisfaction

Ha $\quad: \beta<0$. There is a relationship between soft skills and tourist satisfaction

b. Determine the decision making criteria by comparing the value of $t$-counted with the t-table, namely:

Value of t-counted > value of t-table, then $\mathrm{H} 0$ is rejected

Value of t-counted < value of t-table, then $\mathrm{H} 0$ is accepted

Anova test is used to determine the value of $t$ counted

If Sig. (2-tailed) $<\mathrm{a}$, then $\mathrm{H} 0$ is rejected

If Sig. (2-tailed) $>\mathrm{a}$, then $\mathrm{HO}$ is accepted c. Interpretation of the results of data analysis. Correlation testing in this study was processed using SPSS software on data obtained from the responses of respondents. To determine the extent

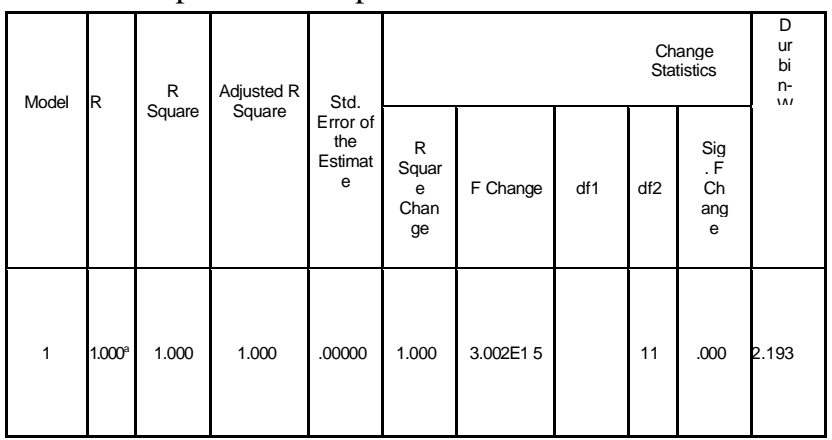

of the role of soft skills in tourist satisfaction, the value of determination is used as shown in table 4.3 below.

To analyze and determine how much effect the independent variable has on the dependent variable, the value of $\mathrm{R}$ Square is determined, in this case 1,000. From statistical calculations, the value of determination of 1 is obtained.

Based on table 4.3 above, the interpretation of the coefficient of determination shows that the effect of soft skills on tourist satisfaction is $100 \%$. Thus it can be concluded that the role of soft skills is very large or very strong in tourist satisfaction.

Anova

\begin{tabular}{|l|r|l|l|l|l|}
\hline \multicolumn{1}{|c|}{ Model } & $\begin{array}{r}\text { Sum of } \\
\text { Squares }\end{array}$ & Df & Mean Square & F & Sig. \\
\hline 1 & 1145.478 & & 104.134 & & $.000^{\mathrm{a}}$ \\
$\begin{array}{l}\text { Regression } \\
\text { Residual }\end{array}$ & .000 & & .000 & & \\
Total & 1145.478 & & & & \\
\hline
\end{tabular}

\section{Coefficients $^{\mathrm{a}}$}

\begin{tabular}{|c|c|c|c|c|c|c|c|c|c|c|c|c|}
\hline \multirow[t]{2}{*}{ Model } & \multicolumn{2}{|c|}{$\begin{array}{l}\text { Unstandardized } \\
\text { Coefficients }\end{array}$} & \multirow[t]{2}{*}{$\begin{array}{l}\text { Standar } \\
\text { dized } \\
\text { Coeffici } \\
\text { ents }\end{array}$} & \multirow[t]{2}{*}{$t$} & \multirow{2}{*}{ Sig } & \multicolumn{3}{|c|}{$\begin{array}{l}95 \% \text { Confidence } \\
\text { Interval forB }\end{array}$} & \multicolumn{3}{|c|}{ Correlations } & \multirow{2}{*}{\begin{tabular}{|l}
$\begin{array}{c}\text { Collinear } \\
\text { ty } \\
\text { Statistics }\end{array}$ \\
\\
VIF
\end{tabular}} \\
\hline & $B$ & $\begin{array}{l}\text { Std. } \\
\text { Error }\end{array}$ & & & & $\begin{array}{l}\text { Lower } \\
\text { Bound }\end{array}$ & $\begin{array}{l}\text { Upp } \\
\text { er } \\
\text { Bou } \\
\text { nd }\end{array}$ & \begin{tabular}{|l|} 
Zero- \\
order
\end{tabular} & Partial & $\begin{array}{l}\mathrm{Par} \\
\mathrm{t}\end{array}$ & $\begin{array}{l}\text { Tole } \\
\text { ranc } \\
\text { e }\end{array}$ & \\
\hline $\begin{array}{l}\text { (Const } \\
\text { ant) }\end{array}$ & \begin{tabular}{|l|}
-7.251 \\
$\mathrm{E}-14$
\end{tabular} & .000 & & .000 & $\begin{array}{l}1.0 \\
00\end{array}$ & .000 & .000 & & & & & \\
\hline$x 1$ & -.333 & .000 & -.024 & $\begin{array}{l}- \\
1.60 \\
4 \mathrm{E} 6\end{array}$ & $\begin{array}{l}.00 \\
0\end{array}$ & -.333 & -.333 & .700 & -1.000 & \begin{tabular}{|l}
- \\
.00 \\
9
\end{tabular} & .124 & 8.033 \\
\hline x2 & 1.000 & .000 & .066 & $\begin{array}{l}4.11 \\
2 \mathrm{E} 6\end{array}$ & $\begin{array}{l}.00 \\
0\end{array}$ & 1.000 & $\begin{array}{l}1.00 \\
0\end{array}$ & .499 & 1.000 & $\begin{array}{l}.02 \\
2\end{array}$ & .110 & 9.087 \\
\hline$x 3$ & .500 & .000 & .039 & $\begin{array}{l}2.64 \\
7 \mathrm{E} 6\end{array}$ & $\begin{array}{l}.00 \\
0\end{array}$ & .500 & .500 & .858 & 1.000 & $\begin{array}{l}.01 \\
4\end{array}$ & .130 & 7.694 \\
\hline
\end{tabular}




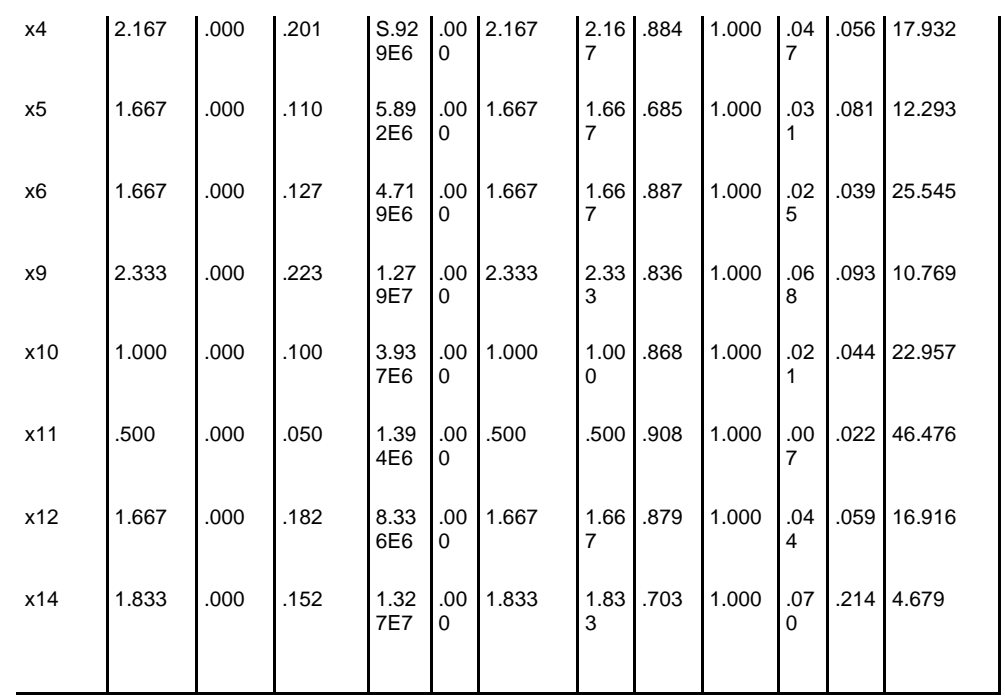

Based on the table above, it can be concluded that the role played by soft skills is very important in supporting the service by the community as tourism actors so that the tourists who come to visit the white sand beach of Parbaba are satisfied with the services provided. This is evident from the response of the respondents who get friendly service from the managers of attractions; make payment of food and drinks honestly; tourists with one another feel the same service, tourists can see that the tourist area managers on the white sand beach of Parbaba can work together to provide satisfying services to them; also managers of tourism can communicate well to tourists; the managers of restaurant businesses have a sense of tolerance between them; the managers of this tourism object are able to provide adequate facilities to tourists; if tourists need help, then the business managers in this tourism object strive to fulfill what the tourists need; also in terms of the prices of food and beverages sold, the entrepreneurs of restaurants in this region still set prices within reasonable limits; this tourism object is equipped with a toilet that is comfortable to use; but in the case of food sold, it still requires greater variety; as well as souvenir items sold, still need more variety or collections; and business people on this tourism object try to influence tourists to buy goods they trade.

\section{CONCLUSIONS AND SUGGESTIONS}

\subsection{Conclusions}

Based on the results of the analysis and discussion in this study, there are several points that can be concluded, namely as follows:

1. Soft skills play an important role in supporting the services provided by the community as tourism actors so that the tourists who come to visit the white sand beach of Parbaba are satisfied with the services provided. This is evident from the response of respondents who stated that they get friendly service from managing the tourism object; make payment of food and drinks honestly; tourists feel the same service with each other; tourists can see that the tourist area managers on the white sand beach of Parbaba work together to provide satisfying services to tourists; also managers of tourism can communicate well to tourists; restaurant managers have a sense of tolerance between them; the manager of this tourism object is able to provide adequate facilities to tourists; if tourists need help, then entrepreneurs in this tourism object try to fulfill what is needed by tourists; also in terms of the prices of food and beverages sold, the entrepreneurs of restaurants in this region still set prices within reasonable limits; this tourism object is equipped with a toilet that is comfortable to use; but in the case of food sold, greater variation is still needed; as well as souvenir items sold, still need more variety or collections; and business people in the region also try to influence tourists to buy their traded goods.

\subsection{Suggestions}

1. To improve service in order to give satisfaction to the tourists, socialization needs to be done to the managers of the tourism object on the white sand beach of Parbaba about the importance of the role played by soft skills, what is meant by soft skills, the importance of providing service and attention to tourists especially when many tourists during the holiday season. In this case the importance of the service that must be provided by the managers of the tourism object on the white sand beach of Parbaba, from offering food and drinks, offering mats and relaxing places to tourists, serving food and drinks to making payments. When tourists are satisfied with the services provided, they will most likely come back to visit.

2. Aspects of comfort and safety of the tourism object also need attention from business managers in order to provide security and comfort to the tourists who come by forming a Safe Guard task force whose function is to manage the safety and security of tourists who come to visit the tourism object of the white sand beach of Parbaba.

\section{REFERENCES}

Chaturvedi Ajir et al.2011. Communicative Approach to Soft and Hard Skill, VSRD International Journal of Bussiness \& Management Research.

Damanik Janianton, 2002. Pengembangan SDM Pariwisata Daerah : Agenda Kebijakan Untuk Pembuat Kebijakan, Jurnal Ilmu Sosial dan Ilmu Politik 6 (1), $105-120$

Emzir, 2013. Metodologi Penelitian Pendidikan Kualitatif \& Kuantitatif. Kolerasional, Eksperimen, Ex post facto, Etnografi, Grounded theory, Action Research, Edisi Revisi, Rajawali Pers. Divisi buku Perguruan Tinggi. PT. Raja Grafindo Persada. 
Evanur Latifah. 2008. UMY Repository umy.acid/bitstream/handled/8 /Juni 2018

Illah Sailah 2008. Pengembangan Soft skill di Perguruan Tinggi, Dirjen Dikti

Phani, Challa, S.S.J. Ram 2013. 60 Soft Skoills Yang Dibutuhkan di Dunia Kerja w.w.w.marketing donut.co.uk/marketing/sales-lead-generation/improve -your soft skill-for better-networking

Nandi. 2008. Pariwisata dan Pengembangan Sumber Daya Manusia. Jurnal GEA Jurusan Pendidikan Geografi Vol.8 No.1

Sharma. 2009. Pengaruh Hard Skill dan Soft skill Terhadap Pencapaian Keunggulan Bersaing Berkelanjutan

Sugiono, 2012, Metode Penelitian Bisnis . C.V. Alfa Beta Bandung. 